Fusion chief resigns over budget cuts

\section{Mirror devices}

\section{and tokamaks}

\section{in conflict}

\section{Washington}

The head of fusion research programmes in the United States Department of Energy (DoE) has resigned in protest at the way in which the Reagan Administration is proposing to allocate research funds between competing magnetic fusion projects.

His decision has apparently been provoked by the decision of the Office of Management and Budget (OMB), in drawing up the recommendation that President Reagan will present to Congress next January, to shift $\$ 25$ million from research into mirror devices being studied at the Lawrence Livermore National Laboratory in California to the Tokamak Fusion Test Reactor (TFTR) at the Princeton Plasma Physics Laboratory in New Jersey.

The most immediate impact, according to Dr Edwin Kintner, who has been head of DoE's research programme since 1977 , and who last week submitted his resignation as associate director of the Office of Energy Research, will be to delay by about three years completion of the expanded Mirror Fusion Test Facility (known as MFTF-B) which many consider to be the principal competitor to the tokamak.

But the Administration's decision has broader implications, for it effectively undermines a strategy which has been developed by the department under $\mathrm{Dr}$ Kintner to diversify magnetic fusion research away from too great a dependence on the success of the Princeton work.

Support for such diversification was first endorsed by the Administration after a report prepared for DoE by an ad hoc committee under the chairmanship of $\mathrm{Dr}$ John S. Foster of TRW Inc. in 1978. This pointed out that although the Princeton tokamak programme was achieving impressive scientific results, many engineering problems remained before a viable power reactor could be built.

Concentrating purely on the tokamak, it said, constituted an "unnecessarily high risk". It suggested that the United States should "pursue fusion on a broad front", primarily into mirror devices but also into alternative designs.

After careful review, DoE selected two of these designs for increased support. One was the reversed field pinch, a combination of the tokamak and mirror designs. The other was the Elmo Bumpy Torus (EBT), under development at the Oak Ridge National Laboratory in Tennessee (see

Nature 1 May, p.3).

Mirror research was given further support by the successful development at the Lawrence Livermore Laboratory of tandem mirrors to plug the ends of a solenoid-containing plasma. As a result, it was decided last year to expand the first MFTF into a tandem mirror machine, MFTF-B, scheduled for completion in about four years' time and to perform at temperatures and confinement times comparable to the performance of the tokamak.

This strategy is now coming apart under the stringent budgetary pressures being applied by the Reagan Administration. The first potential casualty is likely to be the EBT "proof-of-principle" machine (EBT-P), proposed for construction by the Carter Administration under contract with McDonnell Douglas, but cut from DoE's budget by Mr Reagan in March. Although Congress has reinstated the money in an appropriations bill now sitting on the President's desk, which would provide \$14 million for EBT-P in the current year, it seems unlikely that he will sign it.

Overall, the 1982 budget for magnetic fusion does not look too bad. Although this was reduced in March from the $\$ 506$ million proposed by President Carter to $\$ 456$ million - partly by eliminating funds for a centre for magnetic fusion engineering which DoE had previously agreed to build under congressional pressure to move faster on magnetic fusion in general - the latter figure is still

\title{
Cline stripped of research grants
}

\section{Washington}

In a move clearly intended to warn other scientists not to ignore restrictions laid down by the federal government, Dr Martin Cline of the University of California in Los Angeles (UCLA) has been stripped of one of four research grants he receives from the National Institutes of Health (NIH) because he carried out unauthorized experiments on human patients that involved the use of recombinant DNA techniques.

The incident first came to light last autumn, when it was revealed that, while treating patients in Israel and Italy suffering from $\beta$-thalassaemia, Dr Cline used bone marrow cells whose genetic material had been altered by recombinant DNA techniques, even though he had previously told both his university and the two hospitals involved that he would not do so.

Earlier this year, an investigatory committee established by NIH suggested various conditions that should be applied to future grants applications from Dr Cline, who had already resigned as chief of the division of haematology/oncology at UCLA, while retaining his university post as professor of oncology. sufficient to maintain a cost-of-living increase for the current financial year.

As with other federal agencies, however, it is the 1983 budget that is giving the greatest cause for concern in Washington as the Administration seeks further substantial cuts in public spending to reduce the federal deficit while increasing the military budget.

OMB's decision to shift support from the mirror programme to the TFTR "is a precedent-setting decision taken without an adequate hearing or technical discussion", Dr Kintner said last week, adding that he had been unable to persuade DoE to appeal and that it was going "to change the whole policy direction of magnetic fusion research for the future'".

"For the first time we had a policy which made sense for fusion. It did not argue that we should start competing with other forms of nuclear energy by a definite date, but said we should first meet the short-term objective of knowing whether fusion is practical as an energy source. I worked for five years to create cooperative relationships and research strategies which made sense. That is all dead."'

While the strategy of diversified research support has been pursued within DoE, however, it has come under some criticism from the nuclear industry and its congressional supporters who would like to see work proceed on an experimental tokamak reactor as quickly as possible and feel that the DoE strategy may have been overly cautious. David Dickson

In the light of their conclusion that he had violated both federal regulations for the protection of human subjects and NIH guidelines for use of recombinant DNA technology, the members of the committee recommended - and the $\mathrm{NIH}$ director (then Dr Donald Fredrickson) accepted that special prior approval be required for all future grant applications from him for research with either human subjects or recombinant DNA (Nature 4 June, p.369).

It was left to the advisory councils of various NIH institutes funding his research to decide what to do about existing grants. Two of them, the National Cancer Institute and the National Institute of Arthritis, Diabetes and Digestive and Kidney Diseases, have taken no direct action.

The advisory council to the National Heart, Lung and Blood Institute (NHLBI), however, decided on a harsher penalty than merely impressing conditions on future applications. It recommended that $\mathrm{Dr}$ Cline's current grant from the institute be terminated on 31 March 1982, the end of its first year of support.

The grant, a total of $\$ 244,000$, was to have been spread over a period of three years, and covered research into the effec- 
tiveness of the insertion of human $\beta$-globin genes into mouse haematopoietic cells. A condition of this grant was that no work on human subjects should be involved.

In the case of the National Cancer Institute, two grants for which Dr Cline was the principal investigator were reviewed. The first, for research into normal and malignant haematopoietic cell replication, has been allowed to run until its expiry date at the end of next May, and a renewal application is now under consideration.

On the second grant, part of a four-year project in medical oncology with a total cost of $\$ 3.3$ million, the National Cancer Advisory Board has suggested that the grant be continued until 28 February 1982 A renewal grant application has already been submitted by UCLA, with Dr David Golde named to replace Dr Cline as the principal investigator.

Following the decision by $\mathrm{Dr}$ Tom Malone (acting director of NIH) to accept the recommendations of the three advisory boards, Dr Cline has pointed out that the termination of the NHLBI grant eliminates only about 20 per cent of his research support. He has also said that he has not decided whether or not to appeal against the decision. In a letter to NIH written in September, however, Dr Cline strongly criticizes the 14-month delay by the UCLA Human Subject Protection Committee in giving a definitive response to his request for permission to carry out experiments.

One sanction recommended by the NHLBI advisory council which was not endorsed by NIH was that Dr Cline be asked to provide assurances that he will not engage in human experimentation involving recombinant DNA for a three-year period. A memorandum from NIH associate director of extramural research, Dr William Raub, says that he does not believe it appropriate for NIH to impose such a sanction, "nor do I believe we have authority to do so"'.

David Dickson

\section{ARC biotechnology Cottage industry?}

The pips may squeak in British research, but biotechnology forges on. The UK Agricultural Research Council (ARC), whose budget shrank 3 per cent in real terms between 1979-80 and 1980-81, has actually been able to announce the setting up of a new research centre. Admittedly, it is in a portable home (a Portakabin), but it will house twelve researchers and provide a focus for ARC work on monoclonal antibodies.

Costing around $£ 100,000$ for the Portakabin and equipment, and $£ 100,000$ a year to run when it gets going in April next year, the centre will have two resident researchers, four technical staff, and - on average - six visitors from other ARC laboratories.

The goal is to produce a centre of expertise in the handling and creation of hybridomas - which some ARC virologists have found to be tricky things to culture. The resident researchers at the new centre will work on their own projects (for example, suggest ARC officials, on creating hybridomas of cow, pig and sheep cell lines) and assist visitors with their own problems.

The first applications will be to the creation of specific antibodies to viral strains, such as the varieties of calf enteritis virus, to help research and - perhaps create vaccines where these would be commercially useful. To this end the unit will also have production facilities large enough to conduct commercial trials.

Who will profit from this ARC commercialism, however, is a moot point. By law the council must pass patent rights to the National Research Development Corporation, now part of the British Technology Group which includes the National Enterprise Board. Unlike the Medical Research Council, ARC has no direct agreement with Celltech, the company created by the National Enterprise Board a year ago to exploit biotechnical developments in British research establishments and universities (and to pursue its own research); but, says Celltech, it would expect the new British Technology Group to consider them as potential developers of any ARC product. The British Technology Group, however, would be free to approach any company it wished - and that might be a new British Technology Group company specializing in agriculture.

ARC recently suggested that the British Technology Group should set up a kind of agricultural parallel to Celltech - in which, no doubt, the ARC would like to have the same exclusive rights and potential earnings as the Medical Research Council has in Celltech - and this idea is still being considered. The British Technology Group will not reveal what stage negotiations have reached, but the ARC do not seem particularly optimistic.

Celltech itself is certainly interested in veterinary applications of hybridomas, but the company does not want to be thought of as specializing only in monoclonal antibodies. Its first and so far only product is a monoclonal antibody agains interferon, but Celltech's research and development is now evenly divided between monoclonals and recombinant DNA. Celltech also sees no immediate likelihood of involving itself in the genetic manipulation of plants, unlike the ARC, which has the area very much in mind.

Meanwhile ARC was last week still awaiting official confirmation of the European Council of Ministers agreement three weeks ago to go ahead with the European Commission's biotechnology research programme, which will specialize in agricultural applications. ARC has been closely involved with the definition of the programme, and might hope to win up to $£ 100,000$ a year in grants to supplement its own $f 1$ million annual spending in biotechnology - but only if it has the chance to appoint a strong scientific team to the Advisory Committee on Programme Management. This Brussels committee will ultimately examine research proposals within the programme and - by advising the Commission - effectively hand out the cash. Unfortunately ARC is at a far remove from the Department of Industry, which is in touch with Brussels on this matter, and there are fears that the council may not be approached in time for Britain to get strong representation on the committee.

Robert Walgate

\section{Soviet universities}

\section{Research needed}

The Soviet Union must invest more in university science, according to Academician Ivan F. Obraztsov, Minister of Higher and Secondary Specialized Education of the Russian Republic. Writing in Pravda, he claimed that unless academic research is given priority, it will be difficult to train "good cadres" in the new directions needed for the Soviet economy to develop.

Obraztsov said that Soviet universities and higher educational institutions at present receive no capital funds specifically earmarked for science, although they carry out research worth more than 1,200 million roubles each year. Funds for scientific equipment and research materials are not forthcoming, and computers and similar sophisticated equipment appear far later in the universities than in institutes and laboratories run by specialized ministries.

The lack of funds seems to be especially serious in the engineering faculties. Although Soviet industry is committed to a policy of extensive automation, which is made more urgent by the Soviet Union's falling birth rate, the training of future engineers needs to undergo a "major restructuring"'. Obraztsov implied that means of familiarizing students with automated design systems, control systems, production lines and manmachine complexes simply do not exist.

The emphasis on engineers reflects a trend in the Soviet press. After a long "press debate" last year on why Soviet public opinion gives more prestige to the pure than to the applied sciences, the weekly Literaturnaya Gazeta last month published a round table discussion on the role, status and career prospects of Soviet engineers.

One complaint was that since 1948 , engineers' salaries had risen by an average of 20 per cent in real terms, while those of "ordinary" workers had doubled. The participants also noted that young people seem reluctant to apply to engineering colleges. Many of the most prestigious higher technical schools, such as the Leningrad Mining Institute, no longer set competitive entrance examinations, while 